\title{
Effect of Hydroxyapatite From Nile Tilapia (Oreochromisniloticus) Scale on Surface Hardness of Conventional and Resin Modified Glass Ionomer Cement (In Vitro Study)
}

\author{
Astrid Yudhit ${ }^{1,}$, Kholidina Harahap ${ }^{2}$ and Sabrina Chairunnisa Nasution ${ }^{3}$ \\ ${ }^{1}$ Department Dental Material and Technology, Faculty of Dentistry, Universitas Sumatera Utara, Indonesia \\ ${ }^{2}$ Department Dental Material and Technology, Faculty of Dentistry, University of Sumatera Utara, \\ Indonesia \\ ${ }^{3}$ Undergraduate Student, Faculty of Dentistry, Universitas Sumatera Utara, Indonesia \\ *Corresponding author email : yudhitprasetya@ gmail.com \\ Authors email : kholidinaimandaharahap@gmail.com
}

\begin{abstract}
Surface hardness of restoration materials affected its wear resistance and longevity. The addition of hydroxyapatite could improve mechanical properties of restoration material. Hydroxyapatite can be synthesized from fish scales for it contain calcium carbonate. The aim of this study was to evaluate the surface hardness of conventional and resin modified glass ionomers cement by incorporation of different wt $\%$ of hydroxyapatite from Black tilapia (Oreochromisniloticus) scales. Hydroxyapatite was synthesized from black tilapia scales by calcination method. Samples with a diameter of $5 \mathrm{~mm}$ and a height of $2 \mathrm{~mm}$ were made from conventional and resin modified glass ionomer cement, then divided into 7 groups $(\mathrm{n}=10)$, namely control, $2 \mathrm{wt} \%$ GIC, 5wt\% GIC, 8wt $\%$ GIC, $2 \mathrm{wt} \%$ RMGIC, 5wt\% RMGIC, and 8wt\% RMGIC. Surface hardness test was measured with Vickers Hardness Tester. Result showed hardness value from each groups respectively were $49.81 \pm 3.55 \mathrm{VHN}, 34.49 \pm 1.82 \mathrm{VHN}, 32.58 \pm$ 1.61 VHN, $36.63 \pm 3.09 \mathrm{VHN}, 32.05 \pm 3.77 \mathrm{VHN}, 36.23 \pm 4.27 \mathrm{VHN}$, and 19.27 $\pm 1.71 \mathrm{VHN}$. One-way ANOVA test showed a significant differences in all group $(\mathrm{p}<0.05$ ). It can be conclude that hydroxyapatite from fish scale had an effect on surface hardness of conventional and resin modified glass ionomer cement, whereas it decreased the hardness of conventional GIC, yet it increased the RMGIC hardness.
\end{abstract}

Keywords: hardness, hydroxyapatite, fish scale, gic, rmgic 


\section{INTRODUCTION}

Glass ionomer cement (GIC) was first introduced in 1971, then widely use and still popular until now due to its fluoride release characteristics, chemical bond with tooth structure and metal, easy to handling, and low coefficient of thermal expansion. Main component of GIC is basic glass powder, water and polyacid $[1,2]$. Glass ionomer cement is the most suitable material to use in FDI World Dental Federation new preventive dental treatment concept like minimum intervention [3]. Moreover, GIC also used on World Health Organization (WHO)'s atraumatic restorativEtreatment, dental treatment procedure that does not requires complicated techniques [4]. Despite advantages, GIC has poor mechanical properties among other dental restoration materials, and it made GIC has limitation as restoration on high stress bearing area [2]. Some efforts have been done in order to overcome these disadvantages, like incorporation GIC with metals, glass fiber, hydroxyapatite, silica, and CPP-ACP [5].

Resin modified glass ionomer cement (RMGIC) was used in dental clinic on 1991 [6]. RMGIC has main component as same as conventional GIC with an adding of monomer component (typically hydroxyethyl methacrylate/HEMA) and conjoin initiator system (Camphorquinone) [1,2,6]. Moreover, RMGIC was developed to manage aesthetic, shorten the setting time, and improved the mechanical strength of conventional GIC [2,6]. Nevertheless, RMGIC has high flexural strength but low in compressive strength [2].

Some previous studies was done in order to improve the mechanical properties of GIC and RMGIC by adding material as reinforced, such as fibres or particles like silicon carbide $(\mathrm{SiC})$, fluoroapatite nano-bioceramics, and forsteritenanoparticles, and hydroxyapatite [7,8,9]. Hydroxyapatite is a bio-ceramics material that widely used in the biomedical fields due to its similar structures to the main minerals construction of bones and teeth $[10,11]$. Hydroxyapatite can produce from various sources, both natural and synthetic. Natural sources of hydroxyapatite such as mammalian bones [12], clamshells [13], rocks [14], and eggshells [15]. Hydroxyapatite can also be made in the laboratory through a series of chemical processes. There are several methods for making hydroxyapatite crystals, like precipitation methods, biomimetic deposition, solgel method, electro deposition method, and calcinations [16].

Previous studies have been conducted to evaluate the effect of adding hydroxyapatite to glass ionomer cement and these studies different on HA percentage and source. It was reported that adding synthetic HA into GIC and RMGIC can improved the properties of cement, for example adding $8 \mathrm{wt} \%$ HA increased flexural strength [16], 5wt\% HA increased surface hardness of GIC [17], and 2 and $5 \mathrm{wt} \%$ nano hydroxyapatite increased wear resistance of RMGIC [18]. Some studies used HA from eggshell and reported that $8 \mathrm{wt} \%$ [19] increased GIC's flexural strength and $5 \mathrm{wt} \%$ [20] HA increased its hardness.

Fish scale was a waste that can be used as a source of hydroxyapatite $[10,11,21]$. Fish scale containing fats, water, protein, and some chemical compound like calcium phosphate in high concentration. The calcium phosphate in the fish scale can be process to be a hydroxyapatite [21]. Nile Tilapia (Oreochromisniloticus) fish is the top rank production of freshwater fish in North Sumatera province of Indonesia. Base on this fact, we have an interest to utilize Nile fish scales as a source of hydroxyapatite and incorporate it into GIC and RMGIC to improve the properties.

The aim of this study was to evaluate the effect of hydroxyapatite from fish scale (Oreochromisniloticus) on surface hardness of conventional and resin modified glass ionomer cement. In this study, hydroxyapatite particles were adding to GIC and RMGIC by 2,5 , and 8 wt $\%$ of GIC and RMGIC's powder.

\section{MATERIALS AND METHODS}

Materials used in this study were conventional glass ionomer cement for restoration (Fuji IX, GC, Japan), Resin modified glass ionomer cement with shade A3 (Fuji II LC, GC, Japan), and Hydroxyapatite from Nile Tilapia fish (Oreochromisniloticus) scales that produced by using combination methods of alkaline heat treatment and calcination method $[11,12]$.

Synthesis of hydroxyapatite. Fish (Oreochromisniloticus) scale waste was freshly collected from local market in Medan, North Sumatera Indonesia. The fish scales soaked and washed rigorously in distilled water to remove salts and dirty matters then let it dried in open air under the sun light for 2 hours and grounded sifted using 200 mesh (74 $\mu \mathrm{m})$ sieve. The scales splinters were washed with 0.1 $\mathrm{M} \mathrm{HCl}$ and several times with distilled water to remove the protein. Further, the fish scales splinter were treated with $5 \%(\mathrm{w} / \mathrm{v}) \mathrm{NaOH}$, heated and stirred at $70^{\circ} \mathrm{C}$ for 5 hours to eliminated the remaining protein and result a precipitate. These precipitate powders were treated with $50 \%(\mathrm{w} / \mathrm{v}) \mathrm{NaOH}$, heated up to 100 ${ }^{\circ} \mathrm{C}$ and stirred for 1 hour for alkaline heat treatment. 
The powder washed rigorously with deionized water until neutral and then dried at $60{ }^{\circ} \mathrm{C}$ for $8 \mathrm{~h}$. The calcination of the powder was done in $800{ }^{\circ} \mathrm{C}$ for $1 \mathrm{~h}$ to produce the hydroxyapatite (HA).

GIC and RMGIC Samples. In this study, groups were GIC and RMGIC was mixed manually and placed into metal master mould with $5 \mathrm{~mm}$ in diameters and $2 \mathrm{~mm}$ in depth. For the GIC, celluloid strip and glass object was placed on top and bottom of the samples. Then, placed the $1 \mathrm{~kg}$ load on the top of sample until it set for 2 minutes and 20 seconds. For the RMGIC, celluloid strip and glass object was placed on top and bottom of the samples. Then, placed the $1 \mathrm{~kg}$ load on the

top of sample for 5 minutes. The setting proccess was done by using LED light cured unit for 20 seconds with tip unit direction was perpendicular on top of samples and no curing distance. Hardness test. Hardness test was conduct using Vickers hardness tester machine (Future-Tech FM-800, Japan) with load $50 \mathrm{gf}$ for 15 second. Indentation was done 3 times in different areas of samples and then VHN values were averages. Statistical analysis. One-way ANOVA $(p \leq 0.05)$ with post hoc least significant differences (LSD) was used to compare all groups.

\section{RESULT}

In this study, means and SD of Vickers hardness value on GIC groups control, GIC adding 2, 5, and $8 \mathrm{wt} \%$ HA were $49.813 \pm 3.552 \mathrm{VHN}, 34.492 \pm 1.825$ VHN, 32.584 $\pm 1.610 \mathrm{VHN}$, and $36.550 \pm 3.122 \mathrm{VHN}$ respectively as shown in table 1 . Meanwhile, in RMGIC groups data showed means and SD of Vickers hardness were 22.362 $\pm 2.951, \quad 32.050 \pm 3.771$, $36.227 \pm 4.266$, and $19.270 \pm 1.708 \mathrm{VHN}$ for groups control, RMGIC adding 2,5, and $8 \mathrm{wt} \%$ HA, respectively. One way ANOVA analysis present that there was a significant differences between groups $(\mathrm{p}<0.05)$.

Furthermore, post hoc LSD analysis as shown in fig.1, result shows that the surface hardness of GIC was decreased after adding 2, 5, and $8 \mathrm{wt} \%$ hydroxyapatite compared to control group. The data shows that the lowest Vickers hardness was on GIC after adding $5 \mathrm{wt} \%$ hydroxyapatite, and followed by $2 \mathrm{wt} \%$ and $8 \mathrm{wt} \%$ groups. Meanwhile, the Vickers hardness value of RMGIC was increased after adding 2 and $5 \mathrm{wt} \%$ HA. In other hand, it decreased after adding 8wt $\%$ HA. The data shows the highest hardness was on RMGIC $+5 \mathrm{wt} \% \mathrm{HA}$, and the lowest was RMGIC+8wt\%HA. Post hoc analysis shows all group were significant difference compare to control.

Table 1. Mean and standard deviation (SD) of Vickers

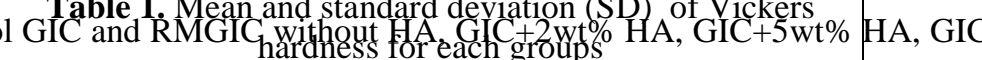
and One way ANOVA between groups.

\begin{tabular}{|c|c|c|c|c|c|c|}
\hline \multirow{2}{*}{$\mathrm{wt} \%$} & \multicolumn{2}{|c|}{$\mathrm{GIC}+\mathrm{HA}$} & \multirow{2}{*}{$\begin{array}{c}\mathrm{p} \\
\text { value }\end{array}$} & \multicolumn{2}{|c|}{ RMGIC + HA } & \multirow{2}{*}{$\begin{array}{c}\mathrm{p} \\
\text { value }\end{array}$} \\
\hline & Mean & SD & & Mean & SD & \\
\hline control & 49.813 & 3.551 & & 22.362 & $\begin{array}{c}2.95 \\
1\end{array}$ & \\
\hline 2 & 34.492 & 1.825 & $0.00 *$ & 32.050 & $\begin{array}{c}3.77 \\
1\end{array}$ & $0.00 *$ \\
\hline 5 & 32.584 & 1.610 & & 36.227 & $\begin{array}{c}4.26 \\
6\end{array}$ & \\
\hline 8 & 36.660 & 3.122 & & 19.270 & $\begin{array}{c}1.70 \\
8\end{array}$ & \\
\hline $\begin{array}{l}\text { there } \\
\text { ANOV }\end{array}$ & $\begin{array}{l}\text { a signi } \\
<0.05)\end{array}$ & int & ences & & & \\
\hline
\end{tabular}

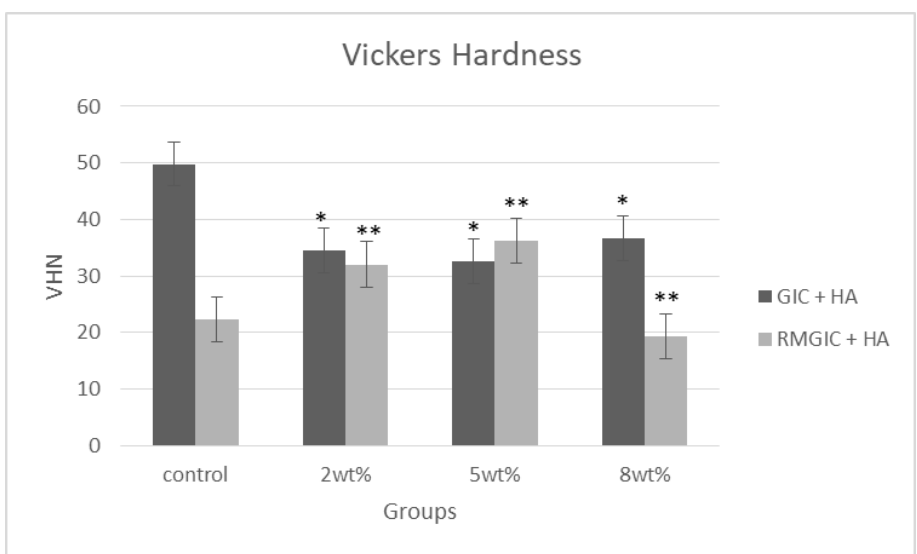

Fig. 1 Vickers Hardness of GIC and RMGIC after adding 2, 5, and 8wt\% Hydroxyapatite from Fish

Scale.*significant difference between control-

GIC+HA (post hoc LSD p<0.05); **significant difference between control-RMGIC (post hoc LSD $\mathrm{p}<0.05)$

\section{DISCUSSION}

One of crucial mechanical properties of dental materials is surface hardness that determines a manifestation of material's resistance for scratching or abrasion. Surface hardness test seems fit to assess longevity and degradation of dental materials, as to remark surface condition after storage in medium, as indication of wear's resistance and durability of materials, and to observe setting process of materials $[2,22]$. 
Hydroxyapatite (HA) or calcium hydroxyapatite is a type of apatite material with the chemical formula (Ca10(PO4)6 $(\mathrm{OH}) 2$ ) which is often applied in the medical and dental fields as substitute material due to its similarity structure to bone and tooth [10,16,21]. HA that produce from natural resources are better than synthetic for its biocompatibility, using uncomplicated method on production, and low cost $[5,10]$. Furthermore, HA from natural source can be ponder as materials that eco-friendly, sustainable, and economical to process [12].

This study used combination, which are alkaline heat treatment and calcination method to produce the hydroxyapatite. The calcination method produced more crystalline HA than alkaline heat treatment. But, calcination method produced more large particles than alkaline heat treatment and less $\mathrm{Ca} / \mathrm{P}$ ratio. Therefore, we used combination method to overcome the problem [12].

In theory, primary setting reaction of glass ionomer cement is in consequence of the acid-base reaction and following with calcium and aluminium ions from glass powder to cross-linking with polyacrylic acid that forms cement matrix [5]. Wilson et al theorem that through adsorption, a complex series of ion exchanges will occur among calcium ions and phosphate from hydroxyapatite and glass powder with help of polyacrylate acid. This interaction will form a layer, known as "intermediate layer", which is highly acid resistance and hard to break.16Hence, as HA add into GIC powder, there will be more salt bridges and cross-linking that form as the powder mixed with liquid, and these will stronger the cement and enhance its biocompatibility.

Our results presented that GIC after adding of 2, 5, and 8wt\% HA exhibit lower Vickers hardness than control group. We assume that this finding occurred due to some factors. First, previous study suggests that particle size has effect on GIC strength. They suggest to use particle size that not too large or too small to achieve a high strength [16,23]. It was reported that a bigger size of HA particles has a porous surface and lower crystallinity than the small ones and had effect on strength of cement [16]. Others reported that nanoparticle HA has better size in occupying void among GIC particles and act as reinforce material in GIC [24]. While in this study, the size of the hydroxyapatite of tilapia scales is estimated only in micro size as the sieve only 200 mesh $(74 \mu \mathrm{m})$. Then, in consequent of high bulk density of HA, previous study recommended that to reach the fusion of HA into GIC low $\mathrm{P} / \mathrm{L}$ ratios [25]. In this study, $\mathrm{P} / \mathrm{L}$ ratio was $1: 1$ as manufacture suggestion and the manipulation was done manually by spatulation, so we assumed that it was hard to achieve a maximal incorporation and reaction among HA and GIC. It was assume that $\mathrm{P} / \mathrm{L}$ ratio and particle size had effect on cement hardness $[23,24]$. Nevertheless, Moshaverinia et al concluded that the main problem in HA modified GIC is the poor of mechanical properties of HA itself [5].

Meanwhile, in RMGIC groups showed that an increase of Vickers hardness after adding HA. RMGIC has two processes on setting reaction, which are acid-base and polymerization. These two reactions made RMGIC have a complicated structure and to reach an optimum property, manufacture's suggestion on duration of curing step is extremely important [6] The liquid of RMGIC that used in this study containing HEMA (25-50\%) and UDMA (1-15\%) [26]. It was reported that there is a good interaction between HEMA and HA as in physicochemical, it was the Lewis acid-base interaction among HEMA as the electron giver and HA as the receptor. Furthermore, HEMA monomer had strong acid-base interaction with HA surface, so that it could act as coupling agent. Thus, the existing of HEMA and HA in RMGIC can enhance the hardness of RMGIC [27].

Moreover, RMGIC showed the highest hardness was on $\mathrm{RMGIC}+5 \mathrm{wt} \% \mathrm{HA}$, and the lowest was RMGIC+8wt\%HA. These result similar to previous study which had reported that mechanical properties of GIC/RMGIC would improve when adding less than $5 \mathrm{wt} \%$ and will decreased if adding more than $5 \mathrm{wt} \%$ $[9,17,18,24]$. It was reported that more than $5 \mathrm{wt} \% \mathrm{HA}$ exhibit congregate form within the glass ionomer resin matrix provide as defect sites and may reduce the hardness. Meanwhile, over than $5 \mathrm{wt} \%$ HA could cause incompletely polymerization of resin component of RMGICs and could worst its mechanical properties [18].

\section{CONCLUSION}

It can be concluded that hydroxyapatite from Nile Tilapia fish (Oreochromisniloticus) in 2, 5, and $8 \mathrm{wt} \%$ has effect on surface hardness of GIC and RMGIC. Adding 2, and 5wt\% HA into RMGIC would increase the surface hardness, but adding $8 \mathrm{wt} \% \mathrm{HA}$ decrease the surface hardness. On contrary, adding HA into GIC decrease the surface hardness. Within the limitation of this study, further investigation to evaluate the effect of hydroxyapatite on mechanical properties of GIC and RMGIC are needed. 


\section{ACKNOWLEDGMENTS}

Financial support of this research work is given by University of Sumatera Utara with Talenta USU Funded Contract 2019 Number: 4167/UN5.1.R/PPM/2019 date April $1^{\text {st }} 2019$.

\section{REFERENCES}

[1] Noort R V 2007Introduction To Dental Materials3rd Ed, Philadelphia Elsevier 217

[2] Anusavice KJ 2008Phillips' Science of Dental Materials $11^{\text {th }} \mathrm{Ed}$, India Elsevier 471

[3] Zanata RL, Navarro MF, Barbosa SH, Lauris JR, Franco EB. Clinical evaluation of three restorative materials applied in a minimal intervention caries treatment approach. $J$ Public Health Dent, 63 (4); 221-6, 2003

[4] Frencken JE, Pilot T, Songpaisan Y, Phantumvanit P. Atraumatic Restorative Treatment (ART): rationale, technique, and development. J Public Health Dent, 56; 135, 1996

[5] Moshaverinia A, Roohpour N, Chee WWL, Schricker SR. A review of powder modifications in conventional glass-ionomer dental cements. J Mater Chem, 21;13:19, 2011

[6] Sidhu SK, Nicholson JW. A review of glass ionomer cement for clinical dentistry. $J$ Funct Biomater, 28;7(3); E16, 2016

[7] Bahrami-Abadi M, Khaghani M, MonshiA, Doostmohammadi A, Alizadeh S. Reinforcement of glass ionomer cement: incorporating with silk fiber. Journal of Advanced Material And Processing, 4(3);14, 2016

[8] Moshaverinia A, Ansari S, MoshaveriniaM, Roohpor N, Darr J, Rihman I. Effects of incorporation of hydroxyapatite nanobioceramics into conventional glass ionomer cements (GIC). Acta Biomateralia, 4:432, 2008

[9] Sayyedan F.S, Fathi M.H, Edris H, Doostmohammadi A, Mortazari V, Hanifi A. Effect of forsterite nanoparticles on mechanical properties of glass ionomer cement. Ceramics International. 40: 10743, 2014

[10] Akram M, Ahmed R Shakir I, Wan Ibrahim WA, Hussain R. Extracting hydroxyapatite and its percursors from natural resources. Journal Material Science. 49 (4);1461, 2014

[11] Bahrololoom ME, Javidi M, Javadpoura S, Ma J. Characterisation of natural hydroxyapatite extracted from bovine cortical bone ash.
Journal of Ceramic Processing Research. 10(2):129, 2009

[12] Pu'ad NASM, Koshy P, Abdullah HZ, Idris MI, Lee TC. Syntheses of hydroxyapatite from natural sources. Heliyon. 8;5(5); e01588, 2019

[13] Huda AN, Subuki I, Ismail MH. Synthesized hydroxyapatite powder from clamshell via chemical precipitation method. Advanced Materials Research. 911:72, 2014

[14] Asri El S, Laghzizil A, Coradin T, Saoiabi A, Alaoui A, M'hamedi R. Conversion of natural phosphate rock into mesoporous hydroxyapatite for heavy metals removal from aqueous solution. Colloids and Surfaces A. Physicochemical and Engineering Aspects. 362(1-3): 33, 2010

[15] Rivera EM, Araiza M, Brostow W, Castano VM, Diaz-estrada DR, Hernandez R, Rodriguez JR. Synthesis of hydroxyapatite from eggshells. Materials Letters. 41(3):128, 1999

[16] Arita K, Yamamoto A, Shinonaya Y,et.al. Hydroxyapatite particle characteristics influence the enhancement of the mechanical and chemical properties of conventional restorative glassionomer cement. Dental Material Journal. 30(5): 672, 2011

[17] Al-Hamaoy A R, Alobiedy A N, Alhille A H. Glass ionomer cement mechanical properties enhancement using hydroxyapatite micro and nano particles. ARPN Journal of Engineering and Applied Sciences. 13(6); 1, 2018

[18] Poorzandpoush K, Omrani LR, Jafarnia SH, Golkar P, Atai M.Effect of nano hydroxyapatite particles on wear of resin modified glass ionomer by tooth brushing simulation. J Clin Exp Dent. 9(3); e372, 2017

[19] Mozartha M, Praziandithe M, Sulistiawati. Pengaruh penambahan hidroksiapatit dari cangkang telur terhadap kekuatan tekan glass ioomer cement. Jurnal B-Dent. 2(1); 75, 2015

[20] Mawadara PA, Mozartha M. Pengaruh penambahan hidroksiapatit dari cangkang telur ayam terhadap kekerasan permukaan GIC. Jurnal Material Kedokteran Gigi.5(2); 8, 2016

[21] Pon-On W, Suntornsaratoon P, Charoenphandhu N, Thongbunchoo J, Krishnamra N, Tang M. Hydroxyapatite from fish scale for potential used as bone scaffold or regenerative material. Materials Science and Engineering C. 62;183, 2016

[22] Shintome LK, Nagayassu MP, Di Nicolo R, Myaki SI. Microhardness of glass ionomer cement indicated for ART technique according 
to surface protection treatment and storage time. Braz Oral Res. 23; 439, 2009

[23] Bala O, Arisu H D, Yikilgan I, Arslan S, Gullu A. Evaluation of surface roughness and hardness of different glass ionomer cements. Eur J Dent. 6(1); 79, 2012

[24] Rahman I A, Masudi S M, Luddin N, Shiekh R A. One-pot synthesis of hydroxyapatite-silica nanopowder composite for hardness enchancement of glass ionomer cement (GIC). Bulletin Materrials Science. 37; 213, 2014

[25] Nicholson JW, Hawkins SJ, Smith JE. The incorporation of hydroxyapatite into glass polyalkenoat ("glass-ionomer") cements: a preliminary study. Journal of Material Science: Materials in Medicine. 4; 418, 1993

[26] Safety data sheet GC Fuji II LC. http://www.gcamerica.com

[27] Arcis RW, Lopez-Macipe A, Toledano M. Mechanical properties of visible light-cured resin reinforced with hydroxyapatite for dental restoration. Dental Materials. 18; 49, 2002 